\title{
Determination of the Types of Air Pollutants Prepondering in the City of Lome in Togo (West Africa)
}

\author{
Lawson Tevi Atator ${ }^{1 *}$, Hodabalo Kamou' ${ }^{1}$ Anissou Bawa², \\ Kodjovi Mawuégnigan Léonard Agbodan', Akpisso Aniko Polo', Hodabalo Pereki', \\ Sêmihinva Ben Akpavi', Koffi Akpagana'
}

${ }^{1}$ Laboratory of Botany and Plant Ecology, University of Lomé, Lomé, Togo

${ }^{2}$ Higher Institute of Agricultural Trades, University of Kara, Kara, Togo

Email: *teviatator@gmail.com, hodabalou@gmail.com, anissoub@gmail.com, agbodana@gmail.com, anikopolo@gmail.com, perekihodabalo@gmail.com, semakpavi@gmail.com, koffi2100@gmail.com

How to cite this paper: Atator, L.T., Kamou, H., Bawa, A., Agbodan, K.M.L., Polo, A.A., Pereki, H., Akpavi, S.B. and Akpagana, K. (2021) Determination of the Types of Air Pollutants Prepondering in the City of Lome in Togo (West Africa). Atmospheric and Climate Sciences, 11, 729-748.

https://doi.org/10.4236/acs.2021.114043

Received: August 8, 2021

Accepted: October 24, 2021

Published: October 27, 2021

Copyright $\odot 2021$ by author(s) and Scientific Research Publishing Inc. This work is licensed under the Creative Commons Attribution International License (CC BY 4.0).

http://creativecommons.org/licenses/by/4.0/

\begin{abstract}
The increase in the urban population and the high concentration of many anthropogenic activities in certain regions of the world lead to atmospheric disturbances. The excess concentration of several chemical elements leads to air pollution. In order to identify the types of air pollutants, a study was carried out in the city of Lomé, the capital of Togo. The objective of this study is to achieve a better knowledge of the types of air pollutants in the city of Lomé. The identification of the various atmospheric pollutants linked to the sources of pollution was made using micro-sensors. The standardized method was used to access target gas concentration levels. The average concentrations of $\mathrm{NO}_{2}$ gaseous pollutants at landfills are on average $0.333 \mu \mathrm{g} / \mathrm{m}^{3} ; 0.403 \mathrm{mg} / \mathrm{m}^{3}$ at the industrial level, at the transport level they are on average $0.434 \mathrm{mg} / \mathrm{m}^{3}$ for the morning and $0.457 \mathrm{mg} / \mathrm{m}^{3}$ for the evening. Concentrations of carbon dioxide $\left(\mathrm{CO}_{2}\right)$ are higher in industrial areas than in others sources of pollution. The average concentration measured at this level is $1632.79 \mathrm{mg} / \mathrm{m}^{3}$. In terms of road transport, in the mornings the average concentration is 1493.23 $\mathrm{mg} / \mathrm{m}^{3}$, in the evening the average concentration is $1354.09 \mathrm{mg} / \mathrm{m}^{3}$. On the other hand, they are lower at the level of the landfills, the average of which is 1265.08 $\mathrm{ppm}$. The highest $\mathrm{SO}_{2}$ concentrations are also observed only in the landfills of Port 1 and Bè_Kpota 2 with concentrations respectively and relatively low and equal to $0.081 \mathrm{mg} / \mathrm{m}^{3}$ and $0.1616 \mathrm{mg} / \mathrm{m}^{3}$. The concentration of ground-level ozone is zero in industries and landfills. On the other hand, at the level of road transport, some values were recorded at the level of two road transports. These are Carrefour Attikoumé Djidjole $\left(17.03 \mathrm{mg} / \mathrm{m}^{3}\right)$ and Carrefour 2 Lions
\end{abstract}


$\left(0.001 \mathrm{mg} / \mathrm{m}^{3}\right)$. The concentrations of carbon monoxide (CO) in the capital at the industrial level are on average $22.57 \mathrm{mg} / \mathrm{m}^{3}$; at landfills it is on average $0.24 \mathrm{mg} / \mathrm{m}^{3}$. In terms of road transport, they are on average $7.890 \mathrm{mg} / \mathrm{m}^{3}$ for the morning and $8.23 \mathrm{mg} / \mathrm{m}^{3}$ for the evening. These results constitute a database for biomonitoring.

\section{Keywords}

Gas Emission, Industries, Transport, Landfills, City of Lomé, Togo

\section{Introduction}

Human activities such as automobile traffic, industrial activities, and massive urbanization are considered to be the main sources of emissions of gaseous and particulate pollutants into the air and their significant concentrations measured in urban environments [1] [2] [3]. In major cities in Europe, Asia and North Ameri$\mathrm{ca}$, air quality monitoring networks are installed with the aim of informing the public authorities and the population in real-time about the different levels of air quality pollution. The studies carried out in these cities underline the urgency of taking measures to reduce the emissions of pollutants into the atmosphere in order to mitigate the impacts on health and the environment [1] [4]. Air quality has received special attention in recent decades. This follows the steady increase in air pollution recorded around the world, resulting in the release into the atmosphere of toxic elements mainly of anthropogenic origin. This causes obvious and significant degradation of the environment and ecosystems [4]. In addition, the ever-increasing development of new technologies has been accompanied by intense industrial, agricultural, commercial and transport activities, promoting a strong rural exodus, particularly in the emerging countries of the South. These are the determining factors of atmospheric pollution in large urban agglomerations that have required phytosanitary studies in order to assess the consequences that toxic pollutants can generate. These pollutants diffused into the atmosphere are constantly captured by plants [5]. In Togo, the city of Lomé is not immune to the problem of air pollution. The air is now in an alarming state in terms of its quality. The increase in air pollution recorded is mainly due to the operation of factories and the lack of public transport, the use of dilapidated vehicles, highly polluting two-stroke mopeds and the sale of illegal gasoline on the sides of the tracks. The objective of this study is to determine the predominant types of air pollutants in the city for better plant biomonitoring and air quality.

\section{Area Study}

The study was conducted in the city of Lomé, the capital of Togo, located in the southwestern tip of the coastal sedimentary basin also called the maritime coastal plain of Togo, between longitudes $1^{\circ} 11^{\prime}$ and $1^{\circ} 17^{\prime}$ East and latitudes $6^{\circ} 06^{\prime}$ and $6^{\circ} 12^{\prime}$ North. Biogeographically, it is located in ecological zone V [6]. It is limited 
to the south by the Atlantic Ocean, to the west by Ghana and the old Kpalimé rails, to the north by street 345 which passes in front of the Agbalepédogan bus station, the boulevard of the new presidency, the road of Togolese Football Federation-Togo 2000 exhibition center, the northern limits of Gnassingbé Eyadéma airport; and to the east by Boulevard Mobutu Sésé Séko and Boulevard Malfakassa (Figure 1). The climate of Lomé is of the Guinean type with four seasons, a large dry season from November to March, a large rainy season from April to July, a small dry season in August, a small rainy season in September and October. The average annual rainfall between 800 and $900 \mathrm{~mm}$. Evapotranspiration in Lomé ranges from $100 \mathrm{~mm}$ in June to $153 \mathrm{~mm}$ in March. The maximum temperatures recorded in March and April vary around $28^{\circ} \mathrm{C}$ while the minimum recorded in August do not drop below $25^{\circ} \mathrm{C}$, resulting in permanent relative heat with thermal differences of around $3 \mathrm{vs}$.

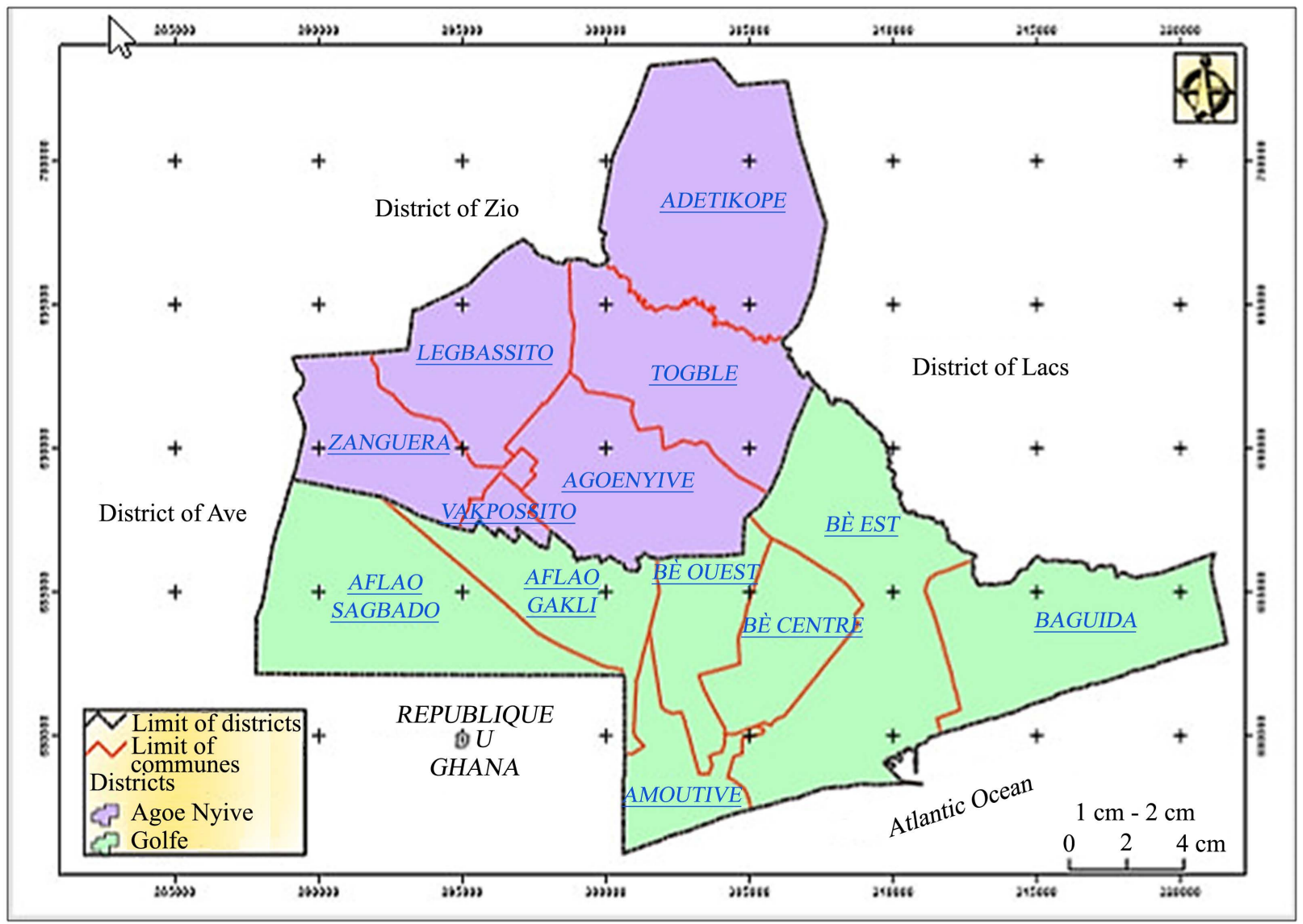

Figure 1. Localization of study area.

\section{Data Sampling}

The measurement of atmospheric pollutants linked to the identified sources of pollution was made using micro-sensors (Table 1). The standardized method adopted by [7]. Zaher Al Barakeh, 2012 was used to access the concentration levels of the targeted gases with a high precision corresponding to specific quality 
objectives. For this study, the 500 series aeroqual sensors equipped with a removable monitor were used. The gases emitted being transported in the direction of the wind, the measurements were carried out according to the direction of the wind at each source. The time ranges for measurements differ from one source to another. Table 2 shows the time slots for the various measurements taken. For each of the sources, the measurements were carried out in no more or strong wind at a temperature of $29^{\circ} \mathrm{C}$ to $33^{\circ} \mathrm{C}$ and relative humidity is between $60.6 \%-80.00 \%$.

Table 1. Characteristics of micro sensors.

\begin{tabular}{ccc}
\hline Micro capteur & Sensibilité aux polluants & Référence \\
\hline $\mathrm{CO}_{2}$ & $0-2000 \mathrm{ppm}$ & $1611150-006$ \\
$\mathrm{NO}_{2}$ & $0-1 \mathrm{ppm}$ & $171151-013$ \\
$\mathrm{CO}$ & $0-25 \mathrm{ppm}$ & $2210152-005$ \\
$\mathrm{O}_{3}$ & $0-0.15 \mathrm{ppm}$ & $0409154-024$ \\
$\mathrm{SO}_{2}$ & $0-10 \mathrm{ppm}$ & $2608152-002$ \\
\hline
\end{tabular}

Table 2. Time slots for the different measurements taken.

\begin{tabular}{cc}
\hline Sources & Plage horaire de mesures \\
\hline Transport & $7 \mathrm{~h}-9 \mathrm{~h}$ et $17 \mathrm{~h}$ à $19 \mathrm{~h}$ \\
Industrie & $10 \mathrm{~h}-12 \mathrm{~h}$ \\
Décharge & $10 \mathrm{~h}-12 \mathrm{~h}$ \\
\hline
\end{tabular}

\section{Data Analyses}

Data were entered by type of anthropogenic source and subjected to descriptive analysis using Excel spreadsheets. The quantities of pollutants were calculated by station.

\section{Results}

\subsection{Variation of Different Types of Pollutants at Landfills}

The quantity of $\mathrm{CO}_{2}$ released is higher at the level of Bè Kpota $2(\mathrm{q}=1352.5 \pm$ 122) followed by Bè Kpota $2(\mathrm{q}=1299.83 \pm 204)$ and Kegué $(\mathrm{q}=1299 \pm 174)$. However, this quantity remains low at the level of Agoe Nyivé $(\mathrm{q}=1217.33 \pm$ 163), Gbossimè ( $\mathrm{q}=1220.66 \pm 102)$ and Tokoin $1(\mathrm{q}=1225.66 \pm 109)$ (Figure 2). The quantity of $\mathrm{NO}_{2}$ released is higher at the level of Bè Klikamè ( $\mathrm{q}=0.436 \pm$ $0.020)$ followed by Avenou $2(\mathrm{q}=0.418 \pm 0.015)$ and Gbossimè $(\mathrm{q}=0.400 \pm 0.047)$. However, this quantity remains low at the level of Bè Kpota1 $(q=0.175 \pm 0.021)$, Kegué $(\mathrm{q}=0.225 \pm 0.004)$ and Port8 $(\mathrm{q}=0.265 \pm 0.018)$ (Figure 3$)$. The quantity of $\mathrm{SO}_{2}$ released is higher at the level of Bè Kpota1 $(\mathrm{q}=0.161 \pm 0.010)$ followed by Port7 $(q=0.816 \pm 0.05)$. However, this quantity remains zero in the other landfills (Figure 4). The amount of CO released is higher at Tokoin1 ( $q=1.34 \pm$ $0.11)$ followed by Tokoin2 $(\mathrm{q}=1.17 \pm 0.025)$ and Véssomé Rail $(\mathrm{q}=0.54 \pm 0.000)$. 
However, this quantity remains low at the level of Avenou $(q=0.04 \pm 0.000)$, Bè Kpota2 $(q=0.18 \pm 0.000)$. On the other hand, the quantity of $\mathrm{O}_{3}$ released is zero (Figure 5).

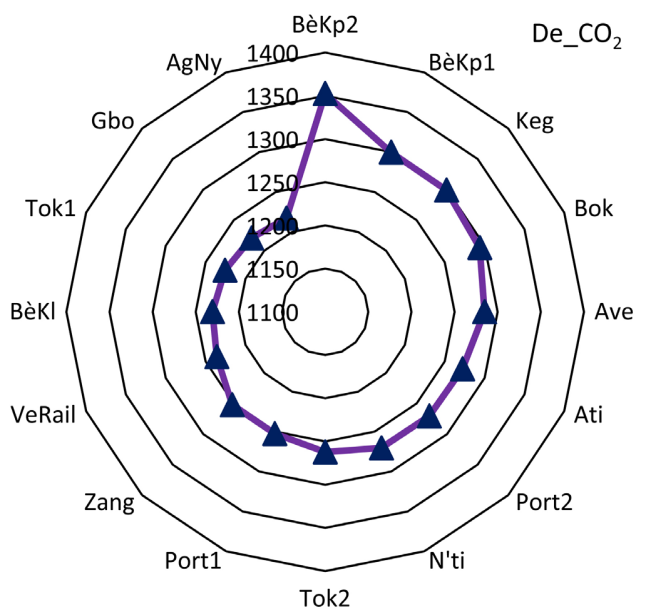

Figure 2. $\mathrm{CO}_{2}$ variation at landfills.

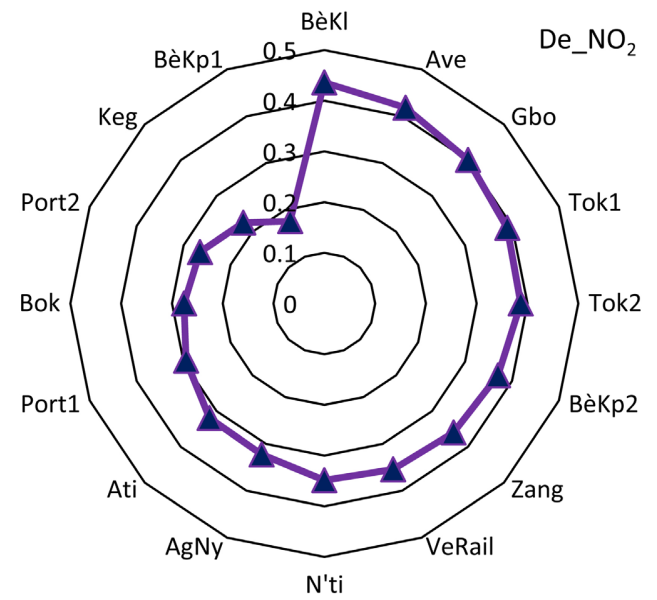

Figure 3. $\mathrm{NO}_{2}$ variation at landfills.

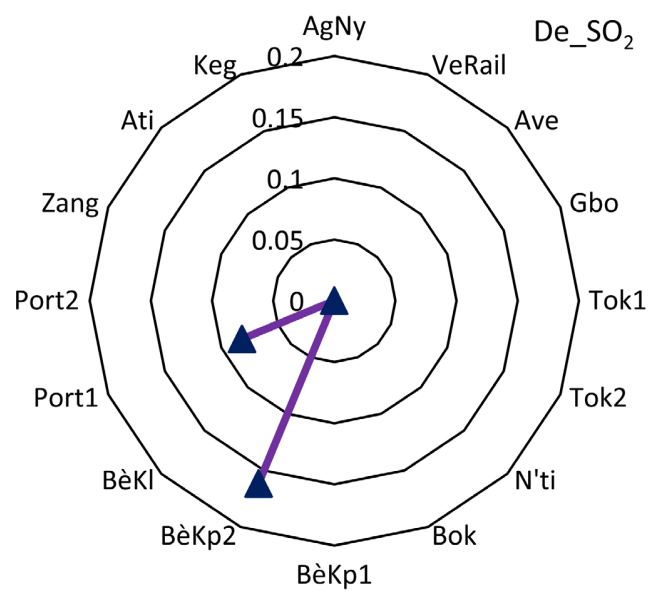

Figure 4. $\mathrm{SO}_{2}$ variation at landfills. 


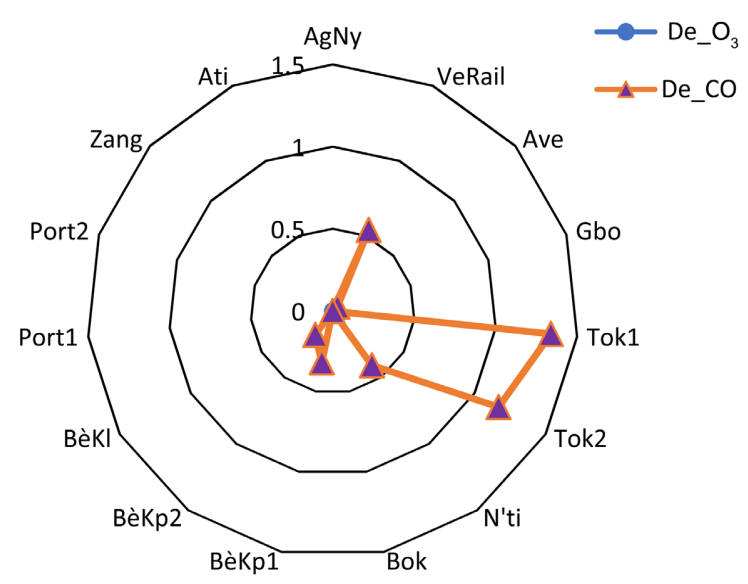

Figure 5. Variation of $\mathrm{O}_{3}$ and $\mathrm{CO}$ at landfills (The amount of $\mathrm{O}_{3}$ is almost zero).

\subsection{Variation of Different Types of Pollutants at the Level of Roads}

The quantity of $\mathrm{CO}_{2}$ released in the morning is higher at the entrance level south campus $(\mathrm{q}=1955.8 \pm 158)$ followed by LE TOGO CINEMA $(\mathrm{q}=1920.8 \pm 104)$, Luminous Fountain $(\mathrm{q}=1907 \pm 164)$, Carrefour Bodjona $(\mathrm{q}=1868.4 \pm 135)$, Carrefour Limousine $(\mathrm{q}=1801.6 \pm 101)$, FIATA $(\mathrm{q}=1799.4 \pm 99.10)$, Carrefour Protestant $(q=1739.2 \pm 308.20)$, Carrefour Echangeur Agoè $(q=1731.6 \pm 302.33)$. It is weak Rondpoint Bè Plage ( $\mathrm{q}=1244.8 \pm 48.30$ ), Carrefour Attikoumé Djidjolé ( $\mathrm{q}$ $=1246.72 \pm 54.66)$ and Colombe de la Paix $(\mathrm{q}=1249 \pm 39.9)$. During the evening, the quantity of $\mathrm{CO}_{2}$ released is high at Carrefour Bodjona $(\mathrm{q}=1951 \pm 335)$, followed by Freau Jardin ( $\mathrm{q}=1764.6 \pm 79.55)$, Carrefour $3 K(\mathrm{q}=1678 \pm 77.35)$ and Carrefour 2 lions $(\mathrm{q}=1644.2 \pm 44.27)$. On the other hand, it is weak Carrefour Nina ( $q=1184 \pm 164)$; Carrefour Marché Bè ( $q=1211.2 \pm 210)$ and Rondpoint Bè Plage $(\mathrm{q}=1216.6 \pm 307)$ (Figure 6$)$. The average quantity of $\mathrm{CO}_{2}$ released during the day is higher at Carrefour Bodjona $(\mathrm{q}=1909.7 \pm 99.9)$ followed by Carrefour 2 Lions $(\mathrm{q}=1659 \pm 88.9)$ and the South Campus entrance $(\mathrm{q}$ $=1642.4 \pm 69.8)$. However, it remains low at Rondpoint Bè plage $(\mathrm{q}=1230.7 \pm$ 30.9); Carrefour Nina ( $\mathrm{q}=1234 \pm 34.2)$ and Colombe de la Paix ( $\mathrm{q}=1244.3 \pm$ 23.9) (Figure 7). The quantity of $\mathrm{NO}_{2}$ released in the morning is higher at the entrance level south campus ( $\mathrm{q}=0.645 \pm 0.05)$ followed by GTA $(\mathrm{q}=0.638 \pm$ $0.04)$, Carrefour Agoe Assiyéyé $(\mathrm{q}=0.592 \pm 0.09$ ), Carrefour boulevard nyekonakpoe $(\mathrm{q}=0.577 \pm 0.035)$, Carrefour 2 Lions $(\mathrm{q}=0.562 \pm 0.01)$, Carrefour interchange Agoe $(\mathrm{q}=0.550 \pm 0.010)$, Carrefour Limousine $(\mathrm{q}=0.542 \pm 0.03)$, Carrefour Leaderprice $(\mathrm{q}=0.521 \pm 0.02)$ and Carrefour ramco assivito $(\mathrm{q}=0.508$ $\pm 0.07)$. It is low Dove of Peace $(q=0.292 \pm 0.000)$, Carrefour Nina $(q=0.309 \pm$ $0.001)$ and Freau Jardin $(q=0.312 \pm 0.003)$. During the evening, the quantity of $\mathrm{NO}_{2}$ released is high at Rondpoint Bè plage $(\mathrm{q}=0.655 \pm 0.005)$, followed by Le Togo Cinema $(\mathrm{q}=0.566 \pm 0.00)$, Carrefour Hanoukope $(\mathrm{q}=0.563 \pm 0.025)$ and Carrefour Todman $(\mathrm{q}=0.533 \pm 0.0027)$ and Rondpoint CIMTOGO $(\mathrm{q}=0.516 \pm$ $0.005)$. On the other hand, it is weak Carrefour $3 \mathrm{~K}(\mathrm{q}=0.364 \pm 0.004)$; Rondpoint Ramco $(\mathrm{q}=0.381 \pm 0.000)$ and Carrefour Bè $(\mathrm{q}=0.385 \pm 0.007)$ (Figure 8). The 


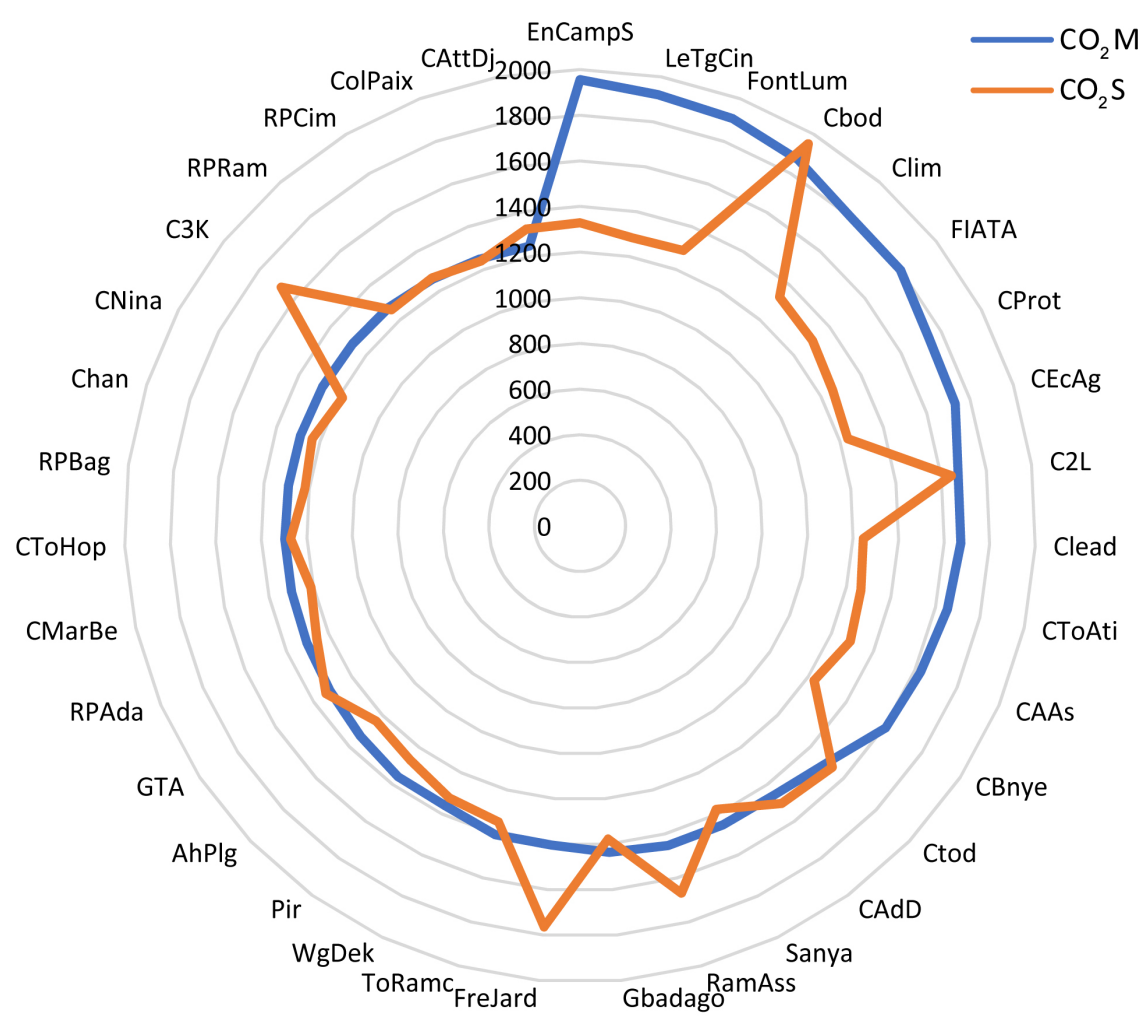

Figure 6. Change in $\mathrm{CO}_{2}$ at intersections morning and evening.

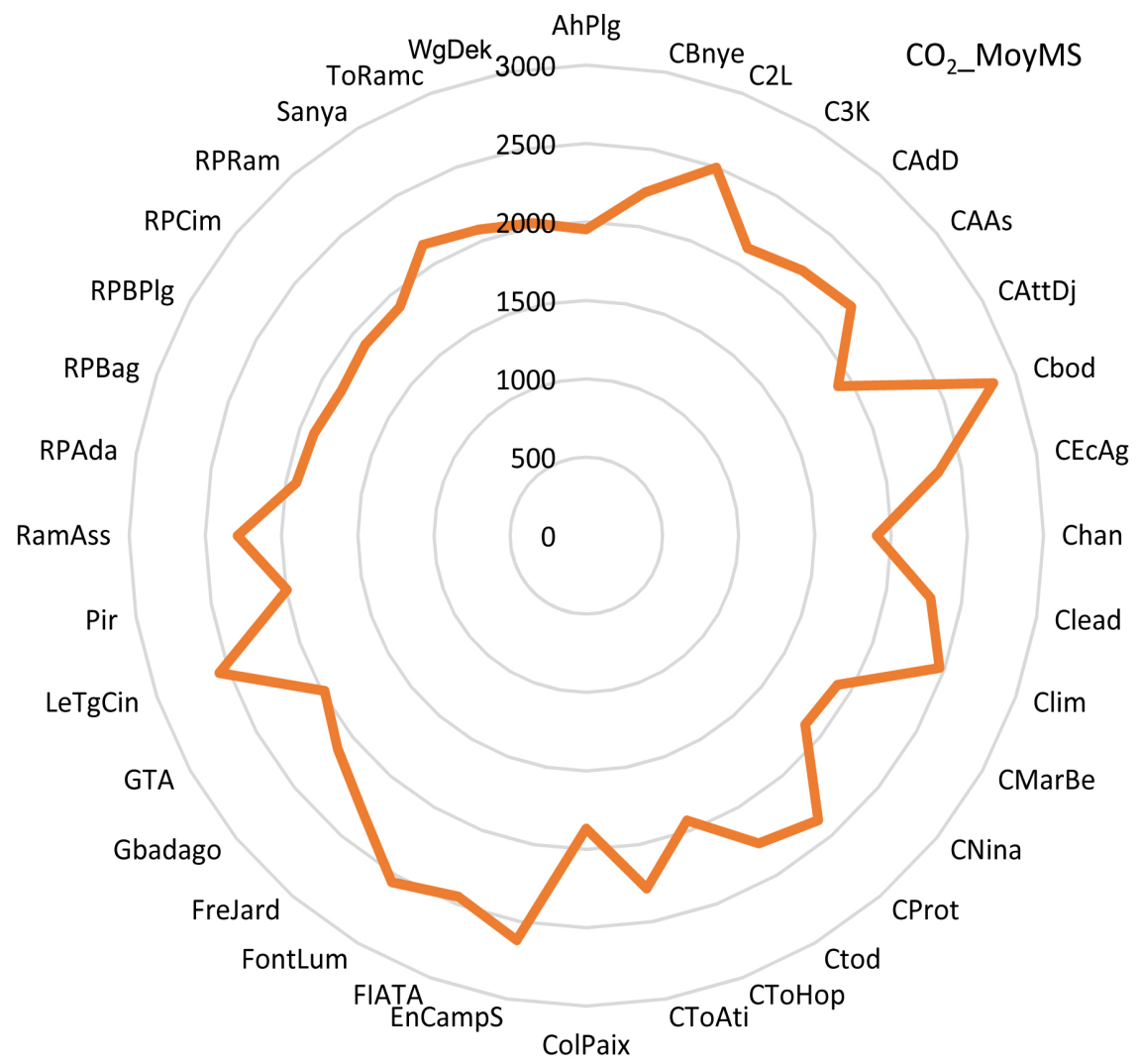

Figure 7. Daily average change in $\mathrm{CO}_{2}$ at intersections. 


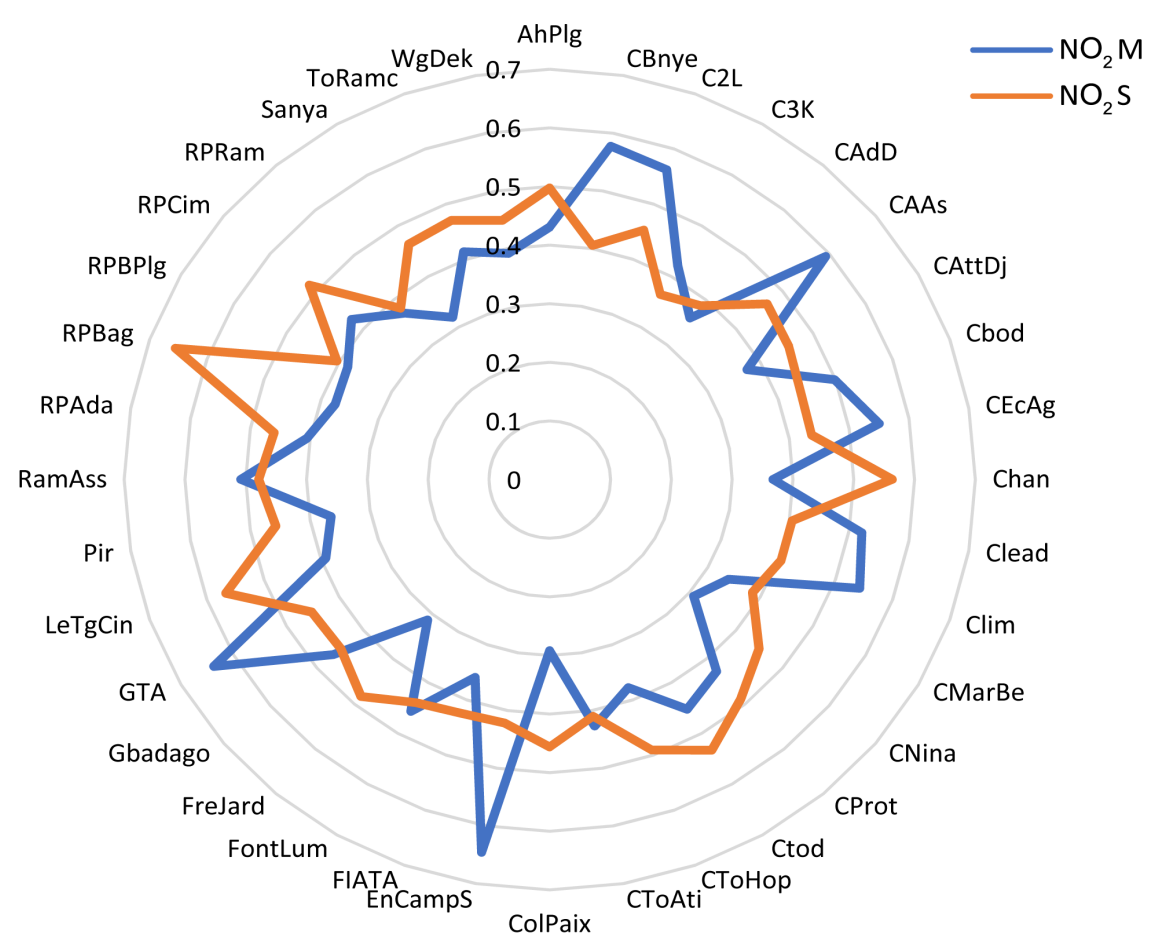

Figure 8. $\mathrm{NO}_{2}$ variation at morning and evening intersections.

average quantity of $\mathrm{NO}_{2}$ released during the day is higher at the level of GTA $(\mathrm{q}=0.545 \pm 0.003)$ followed and of the South Campus entrance $(\mathrm{q}=0.533 \pm$ 0.004), of Carrefour Agoe Assiyéyé ( $q=0.529 \pm 0.008)$, Rondpoind Baguida ( $q=$ $0.515 \pm 0.00)$ and Carrefour 2 Lions $(q=507 \pm 0.001)$. However, it remains low at the level of Dove of Peace $(\mathrm{q}=0.374 \pm 0.001)$; Carrefour Adidogome Customs $(\mathrm{q}=0.373 \pm 0.001)$ and Carrefour Marché Bè $(\mathrm{q}=0.362 \pm 0.006)$ (Figure 9). The quantity of $\mathrm{SO}_{2}$ released in the morning is higher at FIATA $(\mathrm{q}=3.4 \pm 0.55)$ followed by Rondpoint Adakpamè $(\mathrm{q}=1.92 \pm 0.64)$, by GTA $(\mathrm{q}=1.798 \pm 0.69)$, Carrefour marché Bè $(\mathrm{q}=1.372 \pm 0.35)$, Carrefour Tokoin Hôpital $(\mathrm{q}=1.350 \pm$ $0.111)$. It is low Dove of Peace $(q=0.00 \pm 0.000)$, Carrefour Adidogomè Customs $(q=0.00 \pm 0.000)$ and Rondpoint Bè plage $(q=0.054 \pm 0.000)$. During the evening, the quantity of $\mathrm{NO}_{2}$ released is high at the GTA $(\mathrm{q}=2.602 \pm 0.125)$, followed by Entrance campus sud $(\mathrm{q}=2.168 \pm 0.044)$, Carrefour Attikoumé Djidjolé $(\mathrm{q}=1.162 \pm 0.225)$ and Rondpoint Cimtogo $(\mathrm{q}=1.50 \pm 0.250)$. On the other hand, it is weak RAMCO Assivito ( $\mathrm{q}=0.236 \pm 0.001)$; Rondpoint Bè ( $\mathrm{q}=$ $0.218 \pm 0.001)$ and Ahodikpe Plage $(\mathrm{q}=0.108 \pm 0.000)$ (Figure 10) The average quantity of $\mathrm{SO}_{2}$ released during the day is higher at the level of GTA $(\mathrm{q}=2.20 \pm$ $0.011)$ followed and of the FIATA entry $(\mathrm{q}=1.853 \pm 0.001)$, of Rondpoint Adakpamè $(q=1.644 \pm 0.001)$, south campus entrance $(q=1.578 \pm 0.000)$. However, it remains low at Ahodipke plage $(\mathrm{q}=0.099 \pm 0.000)$, Carrefour Adidogome Customs $(q=0.136 \pm 0.001)$ and Carrefour Adidogomè Customs $(q=$ $0.241 \pm 0.001$ ) (Figure 11). The quantity of $\mathrm{O}_{3}$ released in the morning is zero, on the other hand in the evening is $17.03 \pm 3.254$ at Carrefour Attikoumé 


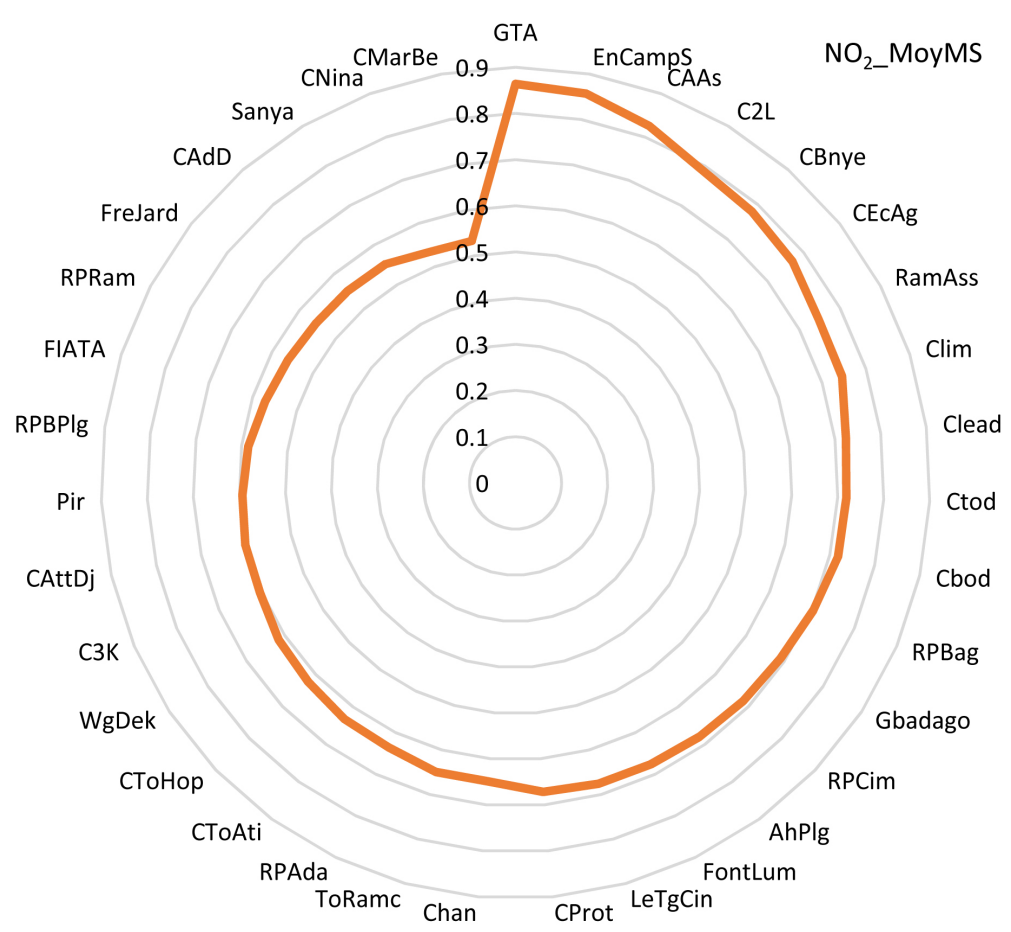

Figure 9. Daily average variation of $\mathrm{NO}_{2}$ at intersections.

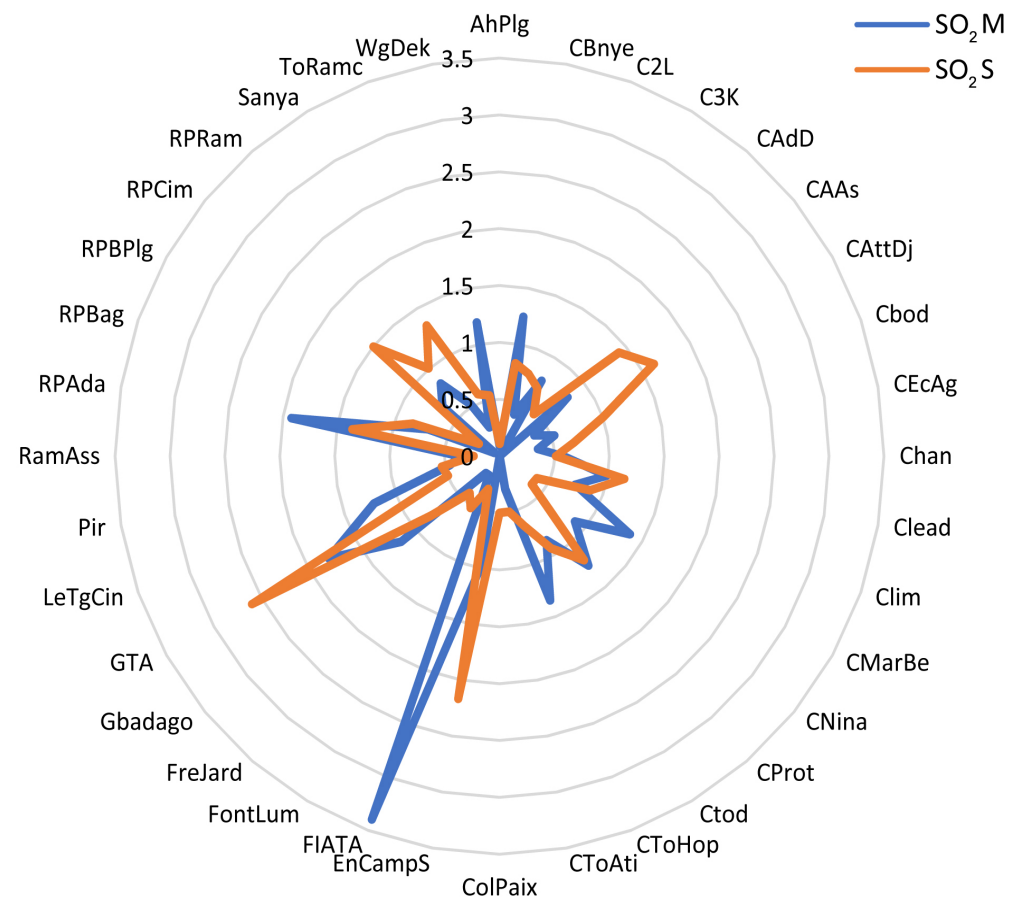

Figure $10 . \mathrm{SO}_{2}$ variation at intersections morning and evening.

Djidjolé (Figure 12). The average quantity of $\mathrm{O}_{3}$ released during the day is 8.51 \pm 2.44 (Figure 13). The amount of $\mathrm{CO}$ released in the morning is higher at Le Togo Cinema ( $\mathrm{q}=34.57 \pm 4.55)$ followed by Gbadago $(\mathrm{q}=32.49 \pm 1.64)$, Carrefour Limousine $(q=17,77 \pm 4.69)$, Carrefour nina $(q=16.5 \pm 5.35)$, Carrefour 


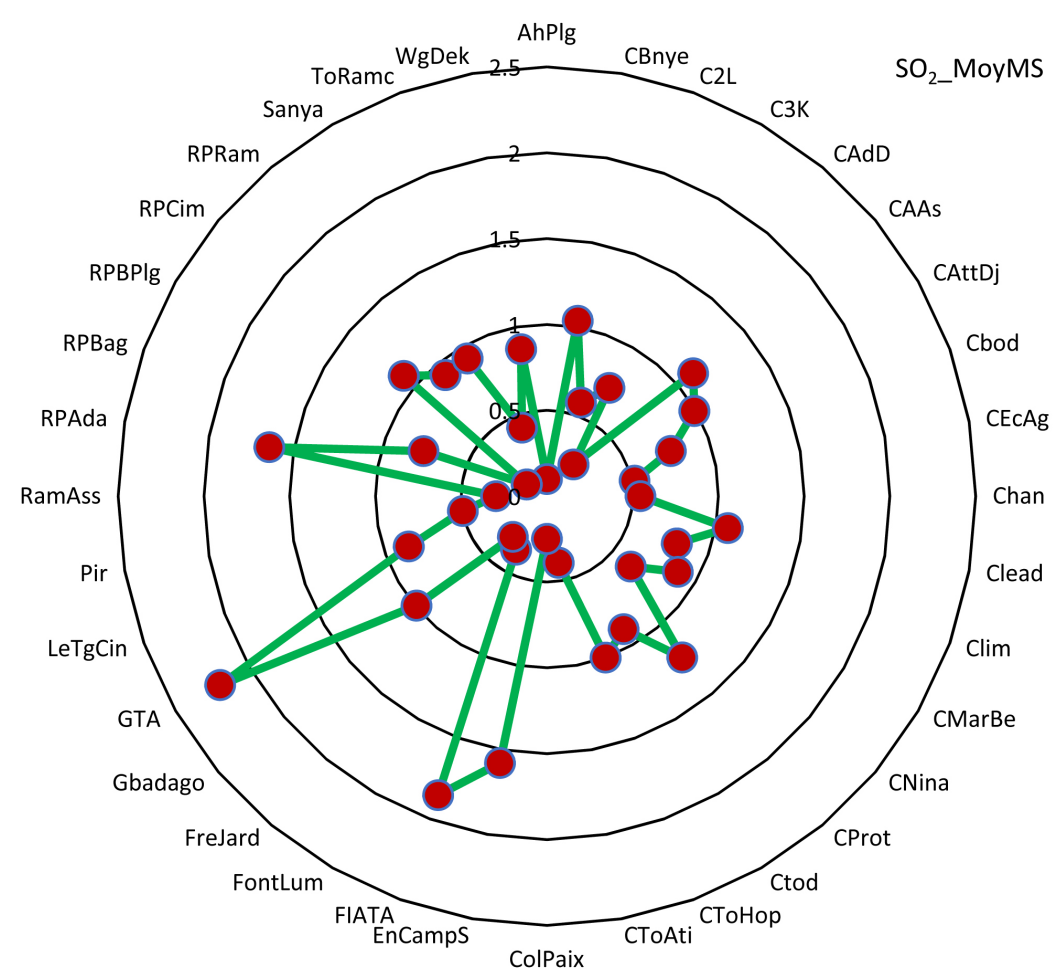

Figure 11. Daily average change in $\mathrm{SO}_{2}$ at intersections.

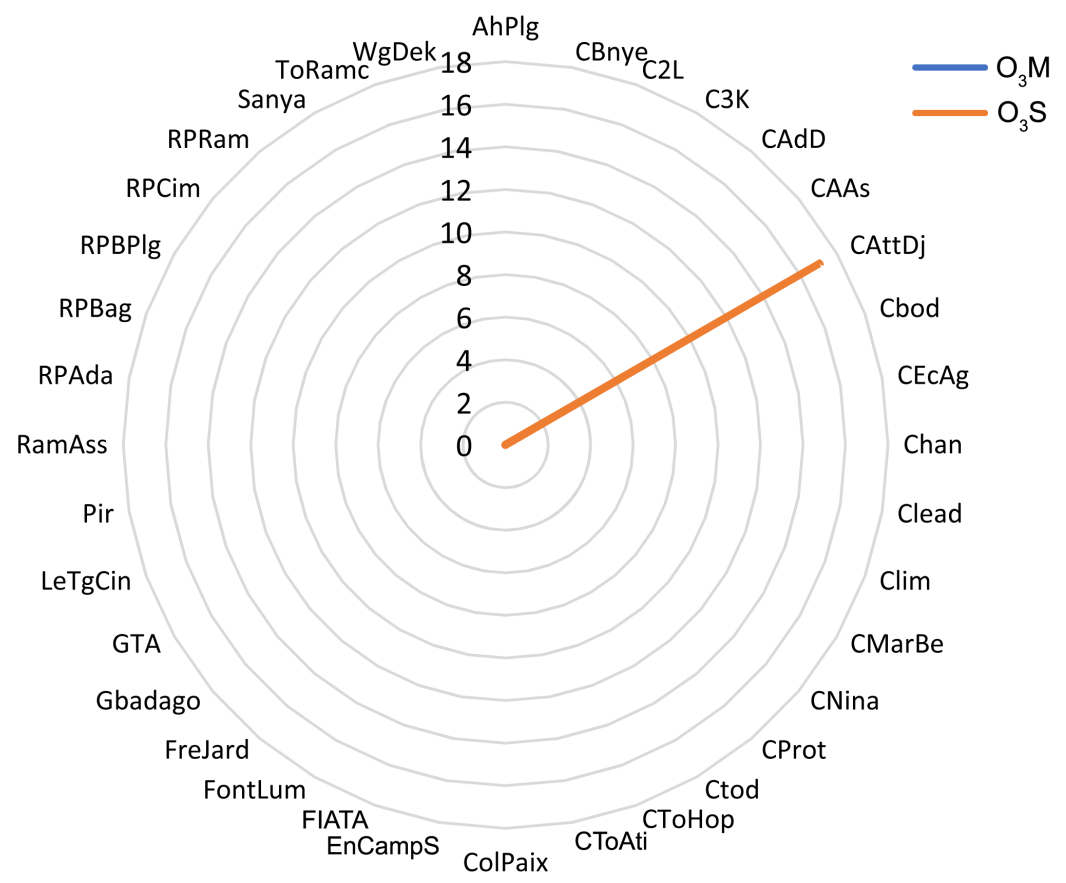

Figure $12 . \mathrm{O}_{3}$ variation at morning and evening intersections.

marché Bè $(\mathrm{q}=16.12 \pm 6.101)$ and Rondpoint Adakpamè $(\mathrm{q}=15.248 \pm 6.02)$. It is zero at Ahodikpe plage $(q=0.00 \pm 0.000)$, Rondpoint Bè plage $(q=0.000 \pm$ 0.000 ) and Sanya. During the evening, the amount of CO released is high at the GTA ( $q=7.859 \pm 3.105)$, followed by South campus entrance $(q=3.67 \pm 0.594)$, 
Carrefour interchange Agoe $(\mathrm{q}=1.556 \pm 0.995)$ and Rondpoint Cimtogo $(\mathrm{q}=$ $5.73 \pm 1.20)$ and Carrefour Agoe Assiyéyé $(\mathrm{q}=14.99 \pm 1.05)$. On the other hand, it is low, the Togo Cinema $(\mathrm{q}=1.768 \pm 0.001)$; Ahodikpe beach $(\mathrm{q}=0.670 \pm$ $0.001)$ and Carrefour Attikoumé Djidjole $(\mathrm{q}=0.581 \pm 0.000)$ (Figure 14 and Figure 15).

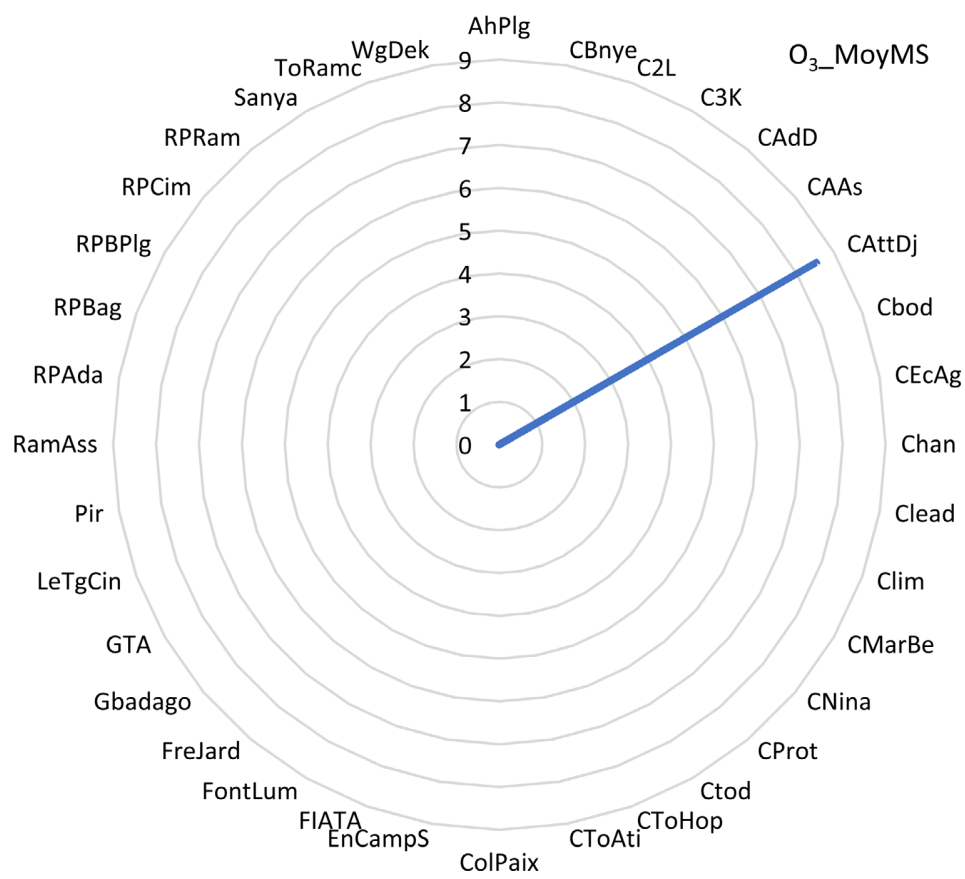

Figure 13. Daily average variation of $\mathrm{O}_{3}$ at intersections.

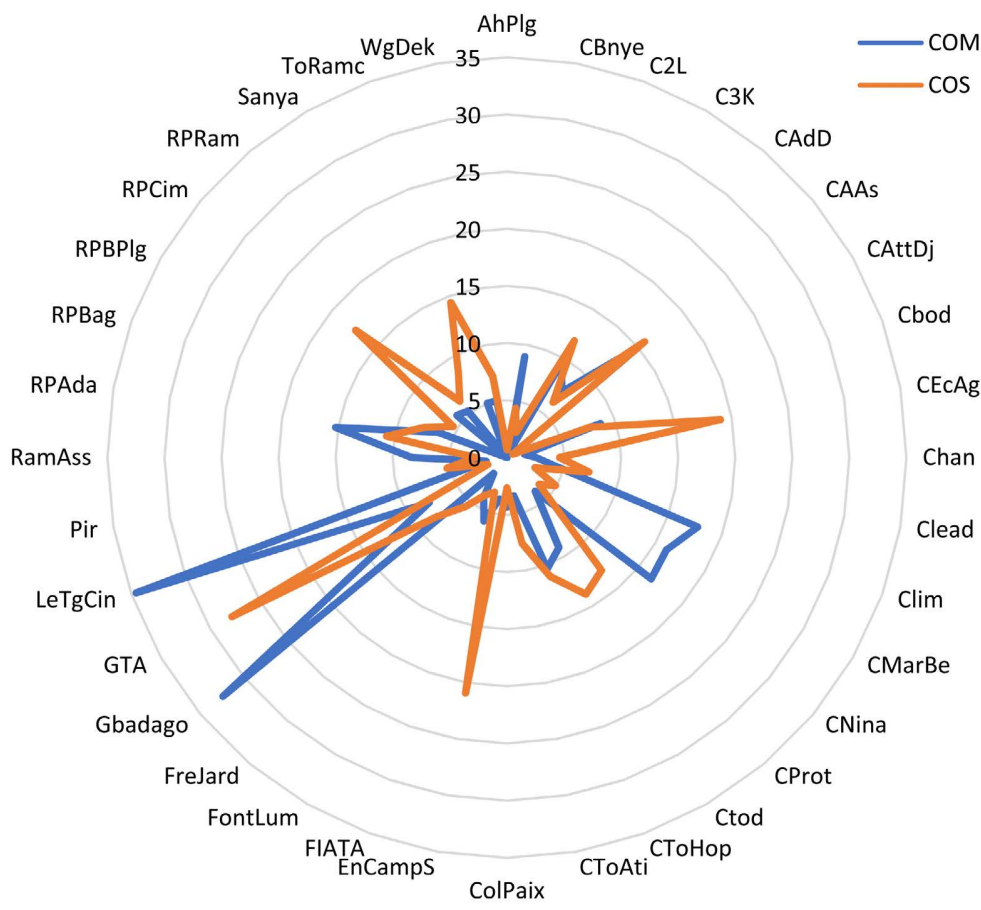

Figure 14. $\mathrm{CO}$ variation at morning and evening intersections. 


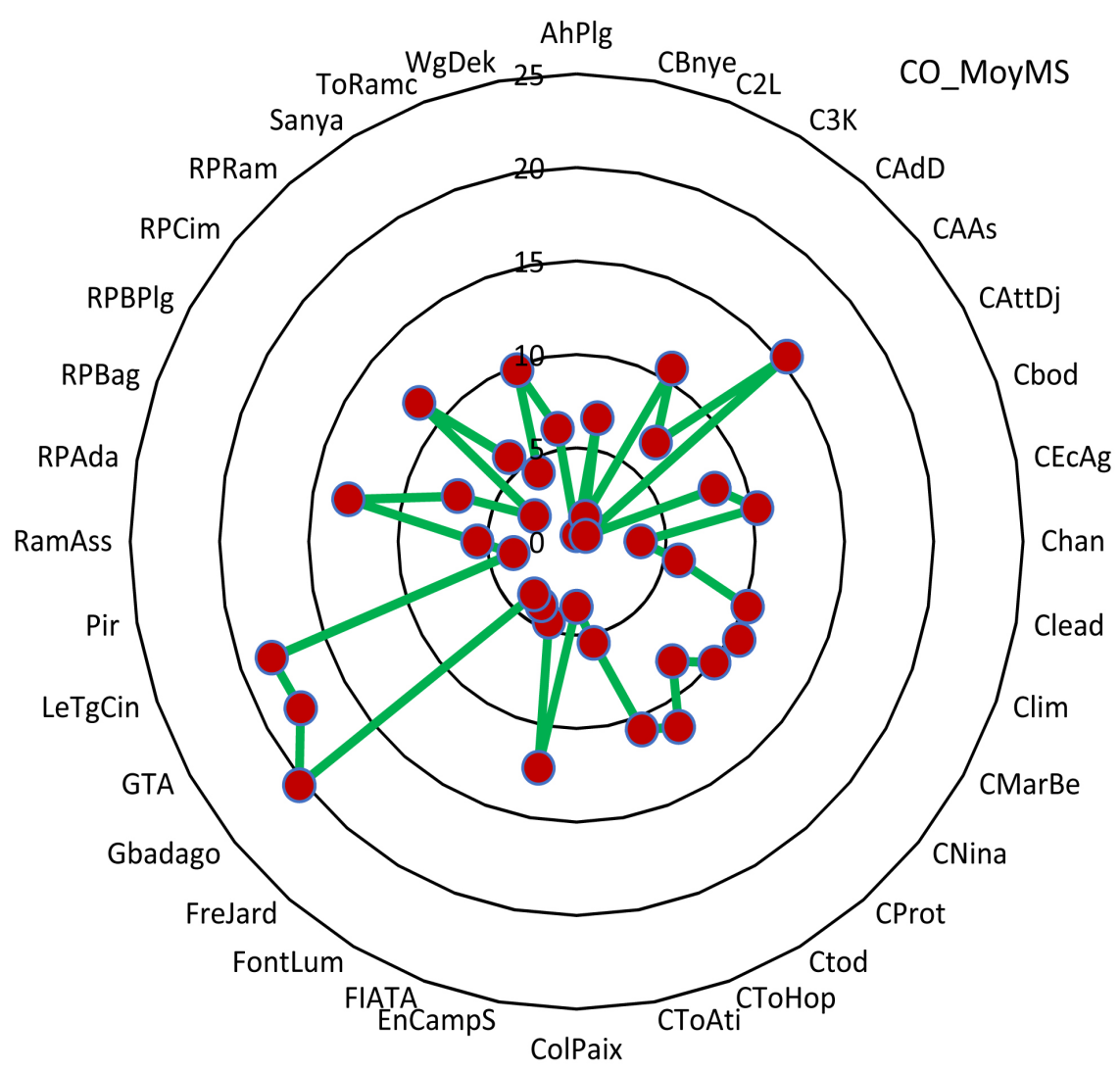

Figure 15. Daily average change in CO at intersections.

\subsection{Variation of Different Types of Pollutants at Industry Level}

The difference between the different variations of $\mathrm{CO}_{2}$ at the industry level is not significant $(\mathrm{P}-\mathrm{Value}=0.001)$. The quantity of $\mathrm{CO}_{2}$ released in the morning is higher at the FanMilk level $(\mathrm{q}=1958.8 \pm 568)$ followed by Docos $(\mathrm{q}=1957.8 \pm$ 304), Brewery ( $q=1918 \pm 256)$. It is weak in Sotraplast $(q=1309.2 \pm 98.30)$, Jet $(\mathrm{q}=1299 \pm 54.21)$ and Donjing $(\mathrm{q}=1249 \pm 39.9)$ (Figure 16). The difference between the different variations of $\mathrm{NO}_{2}$ at the industry level is not significant ( $\mathrm{P}$ Value $=0.001)$. The quantity of $\mathrm{NO}_{2}$ released in the morning is higher at the Amina level $(\mathrm{q}=0.556 \pm 0.001)$ followed by Brewery $(\mathrm{q}=0.520 \pm 0.002)$ and Si$\operatorname{vop}(q=0.505 \pm 0.003)$. It is weak at $\operatorname{Raf}(q=0.182 \pm 0.002)$, Docos $(q=0.284 \pm$ $0.000)$ and WACEM deposition of lomé $(\mathrm{q}=0.294 \pm 0.008)$ (Figure 17). The difference between the different variations of $\mathrm{SO}_{2}$ at the industry level is not significant $(\mathrm{P}$-Value $=0.002)$. The quantity of $\mathrm{SO}_{2}$ released during the day is higher at Induplast level $(\mathrm{q}=0.628 \pm 0.111)$ followed by Cimtogo $(\mathrm{q}=0.36 \pm 0.012)$. It is zero at the level of thirty (30) industries (Figure 18). The quantity of $\mathrm{O}_{3}$ is zero in all industries (Figure 19). The difference between changes in $\mathrm{CO}$ at the industry level is not significant $(\mathrm{P}$-Value $=0.002)$. Only at the industry level Eress Togo that the amount of $\mathrm{CO}$ released during the day was recorded $(\mathrm{q}=0.628 \pm$ $0.111)$ followed by Cimtogo $(q=0.36 \pm 0.012)$. It is zero at the level of thirty (30) industries (Figure 20). 


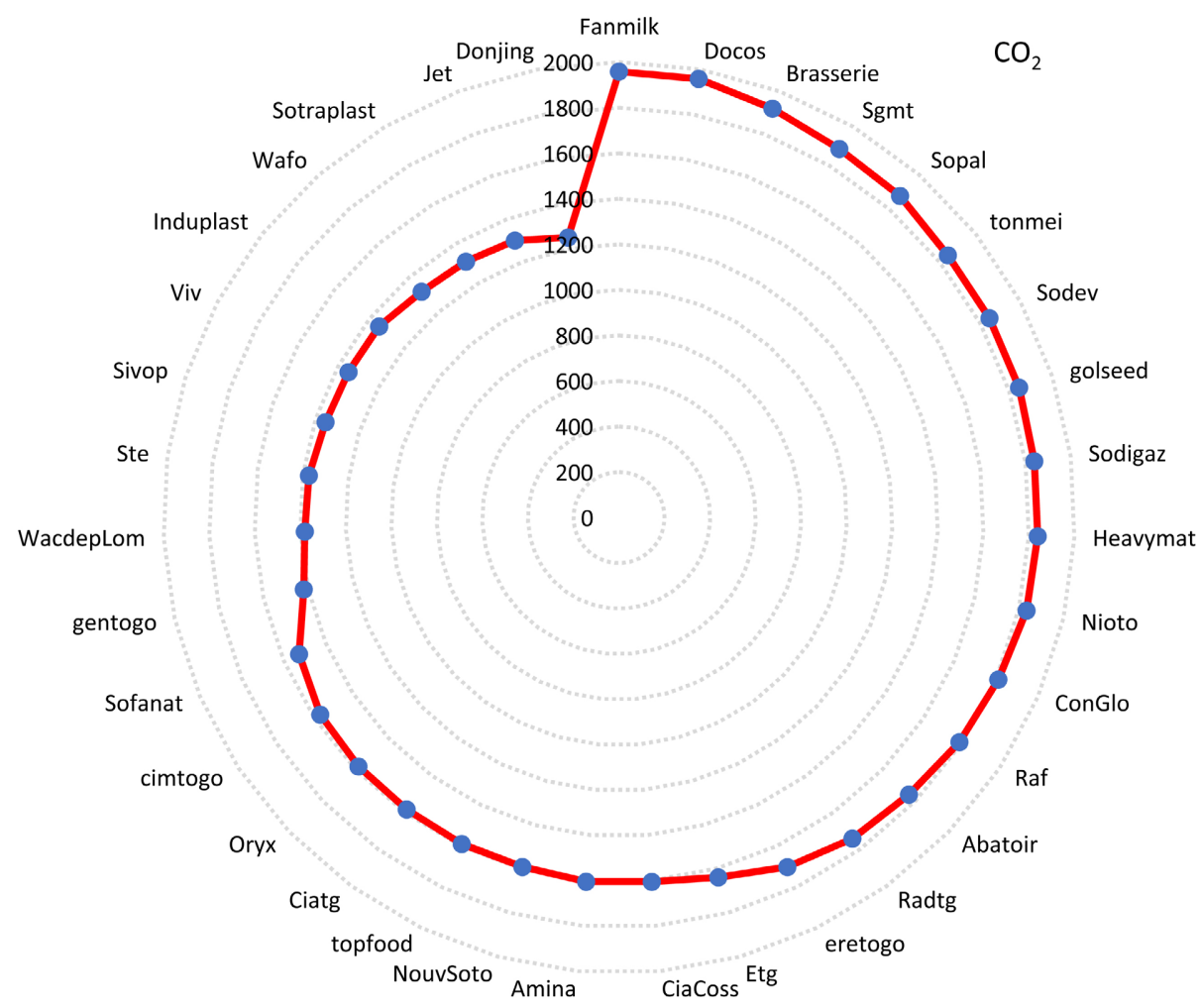

Figure 16. Change in $\mathrm{CO}_{2}$ at industry level.

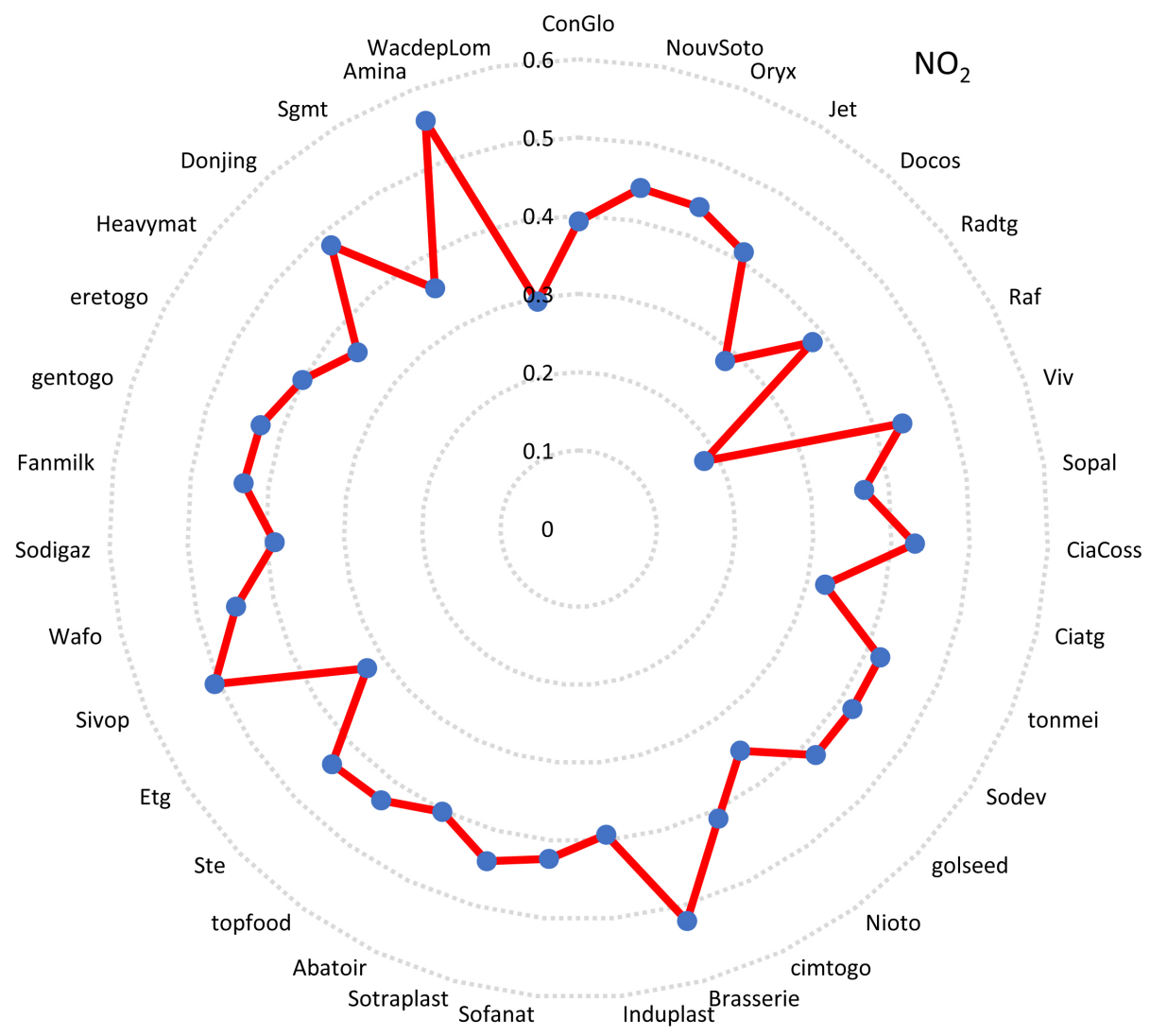

Figure 17. Change in $\mathrm{NO}_{2}$ at industry levels. 


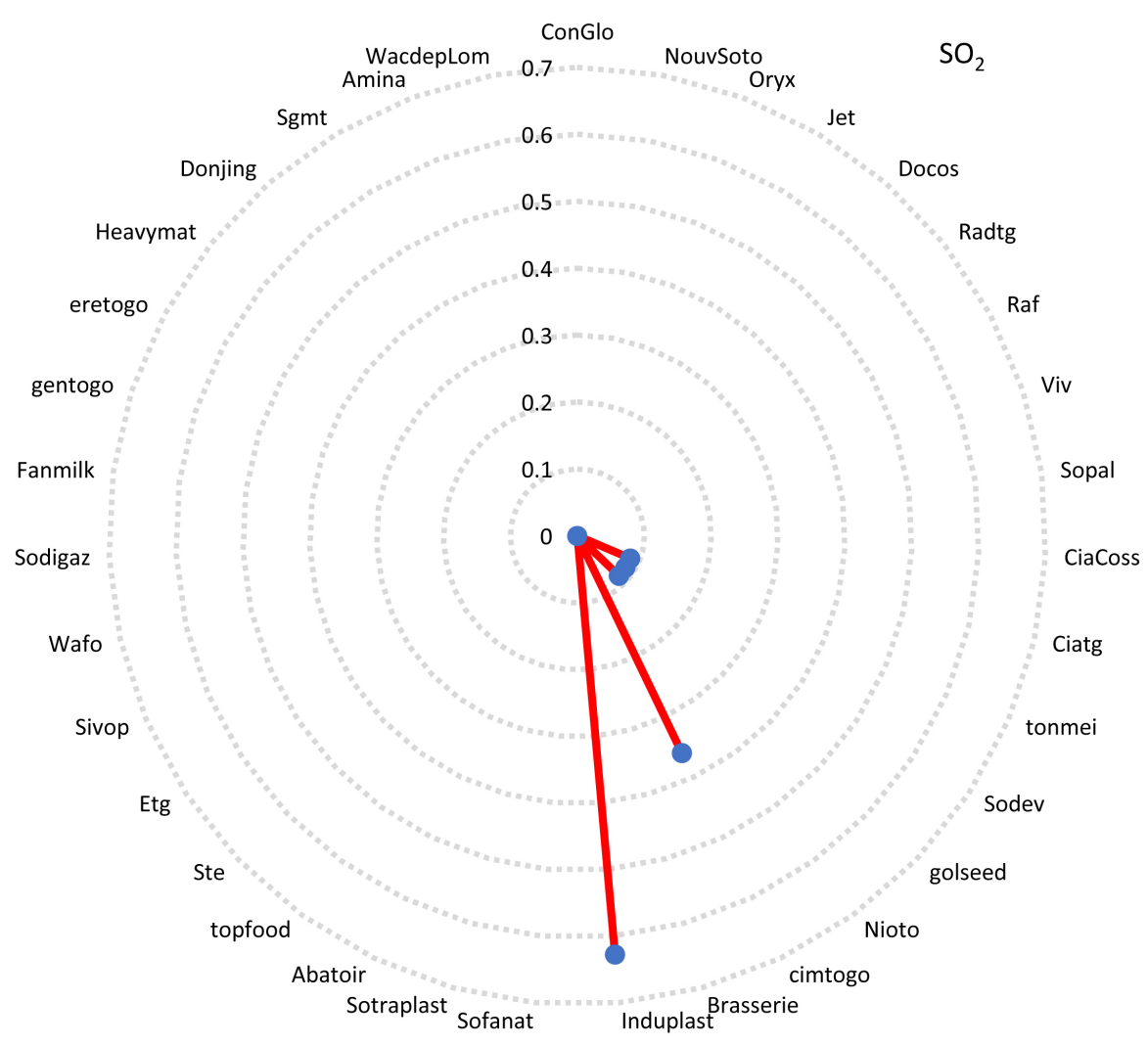

Figure 18. Change in $\mathrm{SO}_{2}$ at industry level.

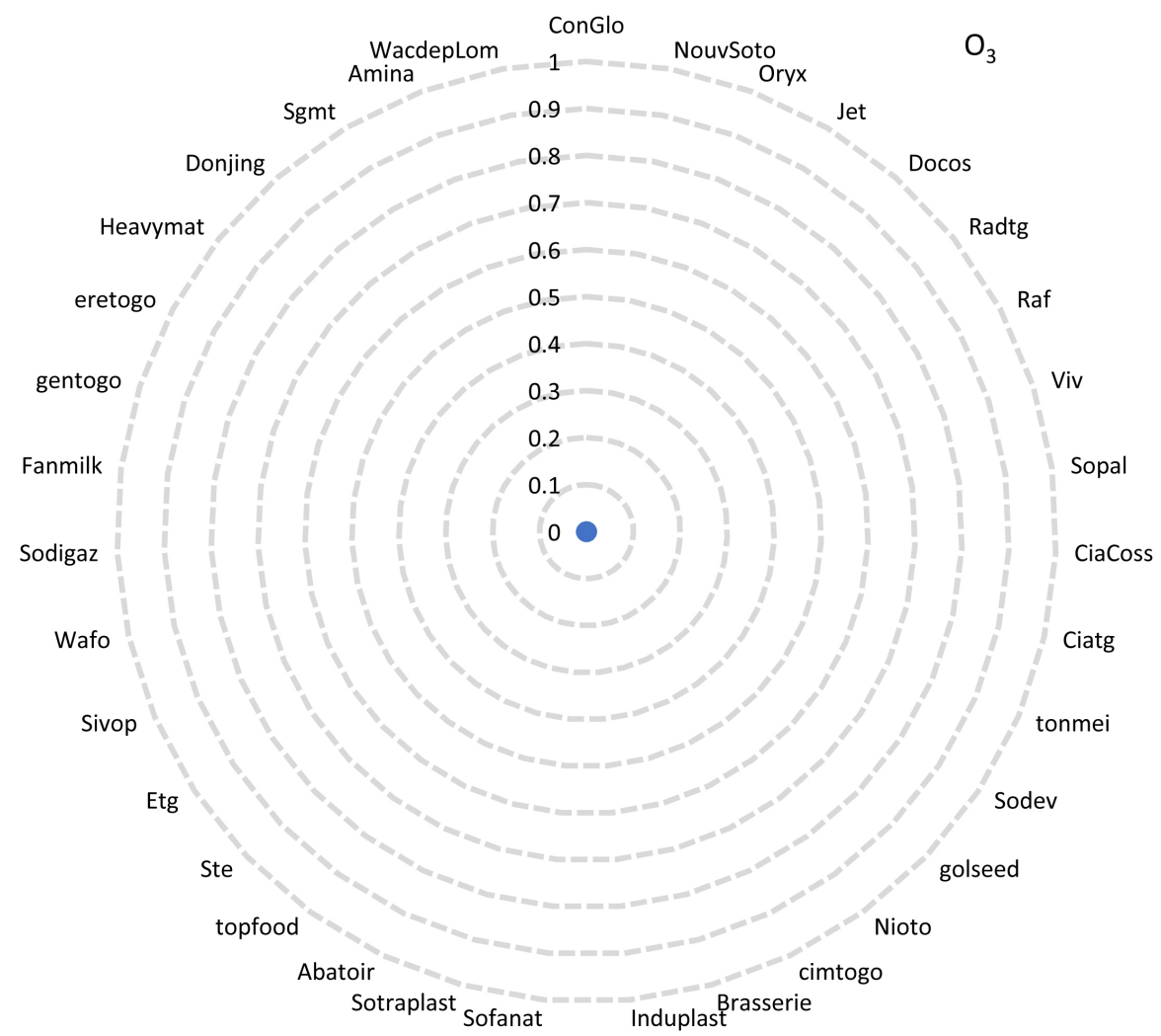

Figure 19. Atmospheric $\mathrm{O}_{3}$ content at industry level. 


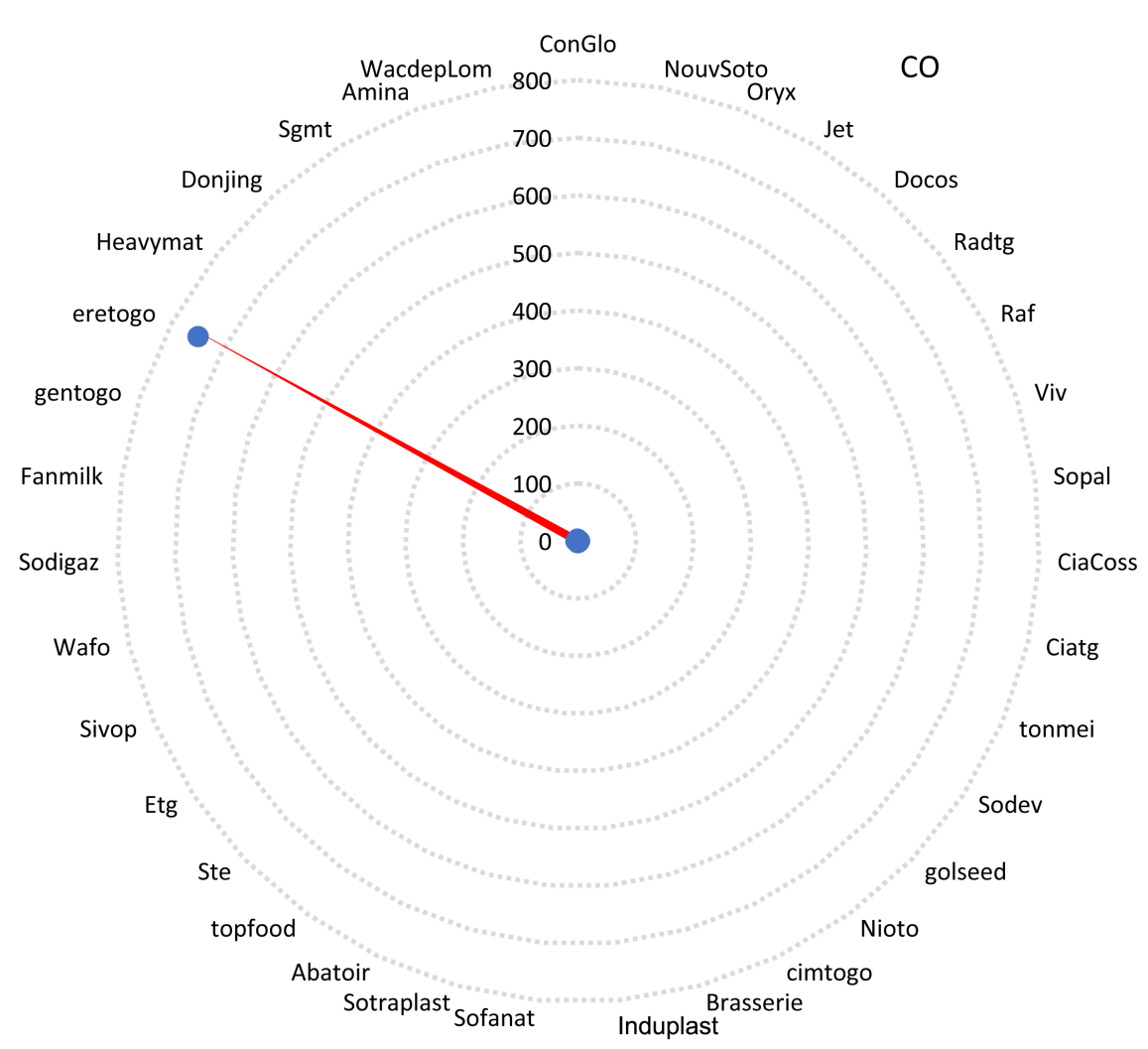

Figure 20. CO variation at industry level.

\section{Discussion}

This chapter presents the concentrations of the various atmospheric pollutants, in particular carbon dioxide $\left(\mathrm{CO}_{2}\right)$, nitrogen dioxide $\left(\mathrm{NO}_{2}\right)$, sulfur dioxide $\left(\mathrm{SO}_{2}\right)$, carbon monoxide (CO) and ozone $\left(\mathrm{O}_{3}\right)$ measured at the level of the main sources of atmospheric pollution in the city of Lomé. In fact, these same pollutants have been reported in several cities in African countries and around the world. These include [4] in Ivory Coast; [8] in Beirut and Lebanon; [9] in Benin; [10] in Dakar. The spatial distributions of $\mathrm{NO}_{2}$ concentrations in the city of Lomé during this study at the landfills level are on average $0.333(\max =0.436 ; \min =0.1755)$ : at the level for the industry it is on average $0.403(\max =0.5566 ; \min =0.182)$ during the study period. In terms of transport, it is on average 0.434 ( $\mathrm{Max}=0.6458$; $\min =0.292)$ for the morning and $0.457(\max =0.655 ; \min =0.3644)$ for the evening. These results show that the highest concentrations were found in transport zones followed by industrial zones. These high values could be explained on the one hand by the increase in the growing number of occasional vehicles and also they could be due to the traffic of large transport trucks. On the other hand, it is port activities and heavy traffic that are likely to emit $\mathrm{NO}_{2}$ that could explain these concentration levels. According to the work of [11], these activities in industrial zones are well known to be the main source of anthropogenic nitrogen oxide emissions into the atmosphere. In addition to road transport sites, high concentrations were also measured at sites dominated by certain industries. This 
is notably the case of the Amina, Brewery and Sivop industries where the average concentration measured respectively is $0.556 \pm 0.08 ; 0.520 \pm 0.04 ; 0.505 \pm 0.06$. These high concentrations measured in Lomé at the level of road transport confirm that $\mathrm{NO}_{2}$ is indeed a tracer of the traffic source as pointed out by [12]. Most vehicles are second-hand and are over 20 years old [9]. These vehicles, which for the most part no longer comply with the air quality standards in force in the states of the European Union (EU), are imported en masse and used in public transport because of their moderate prices. These same results were reported by [9]. In the city of Cotonou in Benin. In fact, in this city of Cotonou, unlike in Lomé, these are the industrial zones that record high concentrations of nitrogen dioxide $\left(\mathrm{NO}_{2}\right)$ followed by road transport. As in the case of $\mathrm{NO}_{2}$, the distribution of carbon dioxide $\left(\mathrm{CO}_{2}\right)$ concentrations in the city of Lomé is higher in industrial areas. In these areas, it is on average $1632.79(\max =1958$; $\min =1249.8)$. In terms of road transport, in the mornings we register an average of $1493.23(\max =1955.8$; $\min =1244.8)$ while in the evening it is $1354.09(\max =1951 ; \min =1184)$. On the other hand, it is lower in terms of landfills whose average is 1265.08 ( $\max =$ 1352.5; $\min =1217.33$ ). This obtained carbon dioxide comes from the oxidation and reduction of other gases [13] [14]. This high concentration at the industrial level is linked to a strong oxidation linked to the gases released by most occasional vehicles. Sulfur dioxide $\mathrm{SO}_{2}$ is also one of the main air pollutants. With water in the atmosphere, it forms smogs or mists as well as aerosols of sulfuric acid. It is the precursor of sulphates, the main component of particles suspended in the atmosphere, also responsible for respiratory problems. In developed countries, anthropogenic $\mathrm{SO}_{2}$ emissions have declined considerably and exponentially from the 1980s until 2005. Emissions into the atmosphere of $\mathrm{SO}_{2}$ from Europe represent 9.6\% of global emissions [15]. The most polluting countries of the European Union in $\mathrm{SO}_{2}$ are the countries of Western Europe (Germany, United Kingdom, Italy, France, Spain, etc.) which emit more than $5 \%$ of $\mathrm{SO}_{2}$ in the world. However, there are also the big polluters such as the United States and Canada (13\% of global emissions). Average $\mathrm{SO}_{2}$ concentrations vary between 0.086 and 0.628 with an industry average of 0.0356 . It is registered at the level of five industries including Induplast, Cimtogo, Tonmei, Sodev and Golseed. However, it remains zero in other industries. Its presence in the five industries could be linked to intensive charcoal production activities using sometimes-traditional furnaces emitting large quantities of fumes or these companies in industrial zones do not yet have a desulphurization unit. The fuel used will mainly consist of rubber wood from the conversion of large rubber plantations. Some studies have shown that charcoal and firewood are the main sources of energy for households in urban areas of Côte d'Ivoire, making biomass an important source of $\mathrm{SO}_{2}$ [16]. As in the case of $\mathrm{NO}_{2}$, high concentrations of $\mathrm{SO}_{2}$ are also observed only in the landfills of Port1 and Bè Kpota2 with concentrations respectively and relatively low, equal to 0.081 , and 0.1616 . It is zero in the other landfills. The $\mathrm{SO}_{2}$ at these landfills would be caused by the surrounding road transport, which is likely to emit $\mathrm{SO}_{2}$. 
In the morning the average concentration is $0.800(\max =3.4 ; \min =0)$ and in the evening the average concentration is $0.838(\max =2.602 ; \min =0.108)$. These results could indicate that the $\mathrm{SO}_{2}$ here is mainly emitted from the road transport source. According to several authors, road transport can constitute an important source of $\mathrm{SO}_{2}$ [17] [18]. In Côte d'Ivoire and Benin, the sulfur content of the fuel produced and marketed is greater than $2000 \mathrm{ppm}$ [19]. This content is more than 40 times higher than the standards applied in most developed countries (50 ppm or less). For the majority of the Abidjan sites (85\%) the average $\mathrm{SO}_{2}$ concentrations are less than $2 \mathrm{ppb}$. The lowest concentrations were measured east of the city of Abidjan where the concentrations vary between $0.4 \mathrm{ppb}$ and $1.1 \mathrm{ppb}$.

The concentration of ground-level ozone is zero in industries and landfills. On the other hand, at the level of road transport, some values were recorded at the level of two road types of transports. These are Carrefour Attikoumé Djidjole (17.03) and carrefour 2 Lions (0.001). It is zero at the level of other road transport. Unlike in other countries such as Ivory Coast, Senegal, Ghana and Benin, overall the presence of $\mathrm{O}_{3}$ is observed in all cities with concentrations ranging from $5.1 \mathrm{ppb}$ to 19.1 and $5.1 \mathrm{ppb}$ to $20.1 \mathrm{ppb}$. These sites benefit from atmospheric conditions favorable to the net production of ozone such as monthly sunshine [20] [21], high relative humidity of the air due to the presence of water vapor from the sea spray and the presence of biogenic from vegetation. The spatial distributions of carbon monoxide (CO) concentrations in the city of Lomé at the industry level are on average $22.57(\max =7.71 ; \min =0)$; at landfills it is on average $0.24(\max =1.34 ; \min =0)$. In terms of road transport, it is on average 7.890 $(\mathrm{Max}=34.57 ; \min =0)$ for the morning and $8.23(\max =27.82 ; \min =0.58)$ for the evening. In addition to other emissions, carbon monoxide emissions are higher at the level of industries in Lomé followed by road transport. The work of [22] has shown that the highest concentrations are recorded at the level of industries and road transport, but fortunately, there is a strong reduction in this gas.

\section{Conclusion}

This article reports on the measurements of gaseous pollutant concentrations carried out using passive sensors carried out during this study. These measurements carried out both in industries, at landfills and at road transport-level have highlighted the spatial distribution of gaseous pollutants $\left(\mathrm{CO}_{2}, \mathrm{NO}_{2}, \mathrm{SO}_{2}, \mathrm{CO}\right.$ and $\mathrm{O}_{3}$ ) by taking into account these different anthropogenic sources of pollution. This original database made it possible for the first time to characterize the average concentration levels of gaseous pollutants. The analysis of the spatial distribution of gaseous pollutants showed a strong spatial variability of pollutant concentrations in the city of Lomé. The average concentrations of gaseous pollutants, in particular $\mathrm{NO}_{2}$, in the city of Lomé during this study at landfills are on average $0.333(\max =0.436 ; \min =0.1755) ; 0.403(\max =0.5566 ; \min =0.182)$. At 
the industry level and the transport level, it is on average 0.434 ( $\mathrm{Max}=0.6458$; $\min =0.292)$ for the morning and $0.457(\max =0.655 ; \min =0.3644)$ for the evening. The concentrations of carbon dioxide $\left(\mathrm{CO}_{2}\right)$ in the city of Lomé are higher in industrial areas. They are on average $1632.79(\max =1958 ; \min =1249.8)$. In terms of road transport, in the mornings we register an average of 1493.23 ( $\max$ $=1955.8 ; \min =1244.8)$ while in the evening it is $1354.09(\max =1951 ; \min =$ 1184). On the other hand, it is lower at the level of the discharges, the average of which is $1265.08(\max =1352.5 ; \mathrm{min}=1217.33)$. The high concentrations of $\mathrm{SO}_{2}$ are also observed only in the landfills of Port1 and Bè Kpota2 with values respectively and relatively low and equal to 0.081 and 0.1616 . The concentration of ground-level ozone is zero in industries and landfills. On the other hand, at the level of road transport, some values were recorded at the level of two road transports. These are Carrefour attikoumé Djidjole (17.03) and carrefour 2 Lions (0.001). It is zero at the level of other road transport. The spatial distributions of carbon monoxide $(\mathrm{CO})$ concentrations in the city of Lomé at the industry level are on average $22.57(\max =7.71 ; \min =0)$; at landfills, it is on average $0.24(\max =1.34$; $\min =0)$. In terms of road transport, it is on average $7.890(\mathrm{Max}=34.57 ; \mathrm{min}=$ $0)$ for the morning and $8.23(\max =27.82$; $\min =0.58)$ for the evening. These results constitute a database for biomonitoring.

\section{Conflicts of Interest}

The authors declare no conflicts of interest regarding the publication of this paper.

\section{References}

[1] Bard, A. (2017) Standard Potentials in Aqueous Solution. Routledge, London. https://doi.org/10.1201/9780203738764

[2] Sleiman, S.F., Henry, J., Al-Haddad, R., El Hayek, L., Haidar, E.A., Stringer, T. and Chao, M.V. (2016) Exercise Promotes the Expression of Brain Derived Neurotrophic Factor (BDNF) through the Action of the Ketone Body $\beta$-Hydroxybutyrate. Elife, 5, e15092. https://doi.org/10.7554/eLife.15092.012

[3] Kampa, M. and Castanas, E. (2008) Human Health Effects of Air Pollution. Environmental Pollution, 151, 362-367. https://doi.org/10.1016/j.envpol.2007.06.012

[4] Bahino, J., Yoboué, V., Galy-Lacaux, C., Adon, M., Akpo, A., Keita, S., Liousse, C., Gardrat, E., Chiron, C. and Ossohou, M. (2019) A Pilot Study of Gaseous Pollutants' Measurement $\left(\mathrm{NO}_{2}, \mathrm{SO}_{2}, \mathrm{NH}_{3}, \mathrm{HNO}_{3}\right.$ and $\left.\mathrm{O}_{3}\right)$ in Abidjan, Côte d'Ivoire: Contribution to an Overview of Gaseous Pollution in African Cities. Atmospheric Chemistry and Physics, 18, 5173-5198. https://doi.org/10.5194/acp-18-5173-2018

[5] Garrec, J.P. and Livertoux, M.H. (2016) Bioindication végétale de l'ozone dans l'agglomération nancéienne durant l'été 1996.

[6] Ern, H. (1979) Die Vegetation Togos. Gliederung, Gefährdung, Erhaltung. Willdenowia, 295-312.

[7] Al Barakeh, Z. (2012) Suivi de pollution atmosphérique par système multi-capteursméthode mixte de classification et de détermination d'un indice de pollution. Doctoral 
Dissertation, EMSE, Saint-Etienne.

[8] Abdallah, C. (2016) Evaluation des émissions et de la modélisation de la qualité de l'air sur Beyrouth et le Liban, Paris Est.

[9] Cachon, F.B.A. (2013) Étude de pollution atmosphérique en Afrique Sub-Saharienne: Cas de Cotonou (Bénin): Caractérisation physicochimique des matières particulaires d'origine urbaine et impact toxicologique sur des cellules épithéliales bronchiques humaines (BEAS-2B) cultivées in vitro. Chimie \& Toxicologie de l'Environnement, Université du Littoral Côte d'Opale en cotutelle avec L'Université d'Abomey-Calavi, Bénin. Doctorat, 282.

[10] Demay, C. (2011) La pollution de l'air à Dakar. Département Géographie, Université de Bourgogne U.F.R Sciences Humaines. Master I, 71.

[11] Krzyzanowski, M. and Cohen, A. (2008) Update of WHO Air Quality Guidelines. Air Quality Atmosphere and Health, 1, 7-13. https://doi.org/10.1007/s11869-008-0008-9

[12] Istrate, A.G., Tauris, T.M., Langer, N. and Antoniadis, J. (2014) The Timescale of LowMass Proto-Helium White Dwarf Evolution. Astronomy \& Astrophysics, 571, L3. https://doi.org/10.1051/0004-6361/201424681

[13] Baneschi, I., Dallai, L., Giazzi, G., Guidi, M. and Krotz, L. (2013) A Method for the Definition of the Carbon Oxidation Number in the Gases Dissolved in Waters and the Redox Variations Using an Elemental Analyser (FlashEA 1112) Preliminary Data from a Stratified Lake. Journal of Geochemical Exploration, 124, 14-21. https://doi.org/10.1016/j.gexplo.2012.07.005

[14] Eksperiandova, L.P., Fedorov, O.I. and Stepanenko, N.A. (2011) Estimation of Metrological Characteristics of the Element Analyzer EuroVector EA-3000 and Its Potential in the Single-Reactor CHNS Mode. Microchemical Journal, 99, 235-238. https://doi.org/10.1016/j.microc.2011.05.005

[15] Smith, S.E., Jakobsen, I., Grønlund, M. and Smith, F.A. (2011) Roles of Arbuscular Mycorrhizas in Plant Phosphorus Nutrition: Interactions between Pathways of Phosphorus Uptake in Arbuscular Mycorrhizal Roots Have Important Implications for Understanding and Manipulating Plant Phosphorus Acquisition. Plant Physiology, 156, 1050-1057. https://doi.org/10.1104/pp.111.174581

[16] Bates, T.S., Calhoun, J.A. and Quinn, P.K. (1992) Variations in the Methanesulfonate to Sulfate Molar Ratio in Submicrometer Marine Aerosol Particles over the South Pacific Ocean. Journal of Geophysical Research: Atmospheres, 97, 9859-9865. https://doi.org/10.1029/92JD00411

[17] Rodrıguez, S., Querol, X., Alastuey, A., Viana, M.-M., Alarcón, M., Mantilla, E., et al. (2004) Comparative PM10-PM2.5 Sources Contribution Study at Rural, Urban and Industrial Sites during PM Episodes in Eastern Spain. Science of the Total Environment, 328, 95-113. https://doi.org/10.1016/S0048-9697(03)00411-X

[18] Tam, P.S., Kittrell, J.R. and Eldridge, J.W. (1990) Desulfurization of Fuel Oil by Oxidation and Extraction. Enhancement of Extraction Oil Yield. Industrial \& Engineering Chemistry Research, 29, 321-324. https://doi.org/10.1021/ie00099a002

[19] U.R.D. (2000) The Quality Project in Afghanistan: Mission 1, 20th July 2002-24th August 2002. Mission Report, Groupe URD, Plaisians.

[20] Maatoug, M., Medkour, K., Hammou, M.A. and Ayad, N. (2010) Cartographie de la pollution atmospherique par le plomb d'origine routiere a l'aide de transplantation d'un lichen bioaccumulateur Xanthoria parietina dans la ville de Tiaret (Algerie). Revue Pollution Atmospheric, 205, 93-101. https://doi.org/10.4267/pollution-atmospherique.734 
[21] Messou, A., Coulibaly, L., Doumbia, L. and Gourene, G. (2013) Plants Diversity and Phytoaccumulators Identification on the Akouedo Landfill (Abidjan, Côte d'Ivoire). African Journal of Biotechnology, 12, 253-264. https://doi.org/10.5897/AJB12.1664

[22] Monks, P.S., Granier, C., Fuzzi, S., Stohl, A., Williams, M.L., et al. (2009) Atmospheric Composition Change-Global and Regional Air Quality. Atmospheric Environment, 43, 5268-5350. https://doi.org/10.1016/j.atmosenv.2009.08.021 